\title{
Renin-Angiotensin System and Coronavirus Disease 2019: A Narrative Review
}

\begin{abstract}
Annamaria Mascolo ${ }^{1,2 *}$, Cristina Scavone ${ }^{1,2}$, Concetta Rafaniello ${ }^{1,2}$, Carmen Ferrajolo ${ }^{1,2}$, Giorgio Racagni ${ }^{3}$, Liberato Berrino ${ }^{1}$, Giuseppe Paolisso ${ }^{4}$, Francesco Rossi ${ }^{1,2+}$ and Annalisa Capuano ${ }^{1,2+}$

${ }^{1}$ Section of Pharmacology "L. Donatelli", Department of Experimental Medicine, University of Campania "Luigi Vanvitelli", Naples, Italy, ${ }^{2}$ Campania Regional Centre for Pharmacovigilance and Pharmacoepidemiology, Naples, Italy, ${ }^{3}$ Department of Pharmacological and Biomolecular Sciences, Università degli Studi di Milano, Milan, Italy, ${ }^{4}$ Department of Advanced Medical and Surgical Sciences, University of Campania "Luigi Vanvitelli", Naples, Italy
\end{abstract}

Although clinical manifestations of the 2019 novel coronavirus disease pandemic (COVID-19), caused by the novel severe acute respiratory syndrome coronavirus 2 (SARS-COV-2), are mainly respiratory symptoms, patients can also develop severe cardiovascular damage. Therefore, understanding the damage caused by SARS-COV-2 to the cardiovascular system and the underlying mechanisms is fundamental. The cardiovascular damage may be related to the imbalance of the renin-angiotensin-system (RAS) as this virus binds the Angiotensin-Converting-Enzyme 2 (ACE2), expressed on the lung alveolar epithelial cells, to enter into cells. Virus internalization may cause a downregulation of ACE2 on host cell surface that could lead to a local increased level of angiotensin II (All) and a reduced level of angiotensin 1-7 (A1-7). An imbalance between these angiotensins may be responsible for the lung and heart damage. Pharmacological strategies that interfere with the viral attachment to ACE2 (umifenovir and hydroxychloroquine/chloroquine) or that modulate the RAS (analogous of A1-7 and ACE2, losartan) are in clinical development for COVID-19. The use of RAS inhibitors has also become a matter of public concern as these drugs may increase the mRNA expression and levels of ACE2 and impact the virulence and transmission of SARS-COV-2. Data on the effect of RAS inhibitors on ACE2 mRNA expression are scarce. Scientific societies expressed their opinion on continuing the therapy with RAS inhibitors in patients with COVID-19 and underlying cardiovascular diseases. In conclusion, RAS may play a role in SARS-COV-2-induced cardiac and pulmonary damage. Further studies are needed to better understand the role of RAS in COVID-19 and to guide decision on the use of RAS inhibitors.

Keywords: COVID-19, renin-angiotensin system, SARS-COV-2, heart damage, pulmonary damage, RAS inhibitors

\section{INTRODUCTION}

The renin-angiotensin system (RAS) is a complex hormonal system composed by different mediators that can affect the cardiovascular, renal, immune, and nervous functions $(1,2)$. Many components of the RAS have been isolated from different tissues (3), including the lung (4). This system is composed by two pathways: the classic RAS and the non-classic RAS, which have 
opposite activities, especially for renal, and cardiovascular functions (2, 5). A component of the non-classic RAS, the Angiotensin-Converting-Enzyme 2 (ACE2) present on the lung surface, has been discovered to be a functional receptor for coronaviruses, essential for triggering their infection (1). Severe acute respiratory syndrome coronavirus 1 (SARS-COV-1) and SARS-COV-2, which are responsible for the SARS and the more recent coronavirus disease 2019 (COVID-19), respectively, are both able to bind the ACE2 in the lung $(6,7)$. Patients affected with COVID-19 show respiratory and flu-like symptoms, which can be complicated by lymphopenia and interstitial pneumonia with high levels of pro-inflammatory cytokines that can lead to acute respiratory distress syndrome (ARDS) and organ failure (8). Although the clinical manifestations of COVID-19 are mainly represented by respiratory symptoms, some patients also developed severe cardiovascular damage (9). In addition, an increased risk of death was found in patients with cardiovascular diseases (9).

Understanding the mechanisms by which the RAS interacts with SARS-COV-2 is fundamental for the treatment of patients with cardiac diseases as showed in the context of metabolic diseases (10). Moreover, considering the interaction between these viruses and the ACE2, concerns were also raised about the use of RAS inhibitors in patients with COVID-19 as they may alter ACE2 mRNA expression and levels and, in this way, impact the virulence and transmission of SARS-COV-2 (11). Therefore, in this review, we aim to summarize the physiological role of the RAS, its implication in the SARS-COV-2 infection, the actual evidence and recommendation on the use of RAS inhibitors, and the ongoing researches of drugs with a potential for the treatment of COVID-19 and acting either by influencing the RAS or disrupting the viral attachment to ACE2.

\section{CLINICAL CHARACTERISTICS OF COVID-19}

First evidence regarding the clinical characteristics of patients with COVID-19 showed the presence of bilateral lung ground glass opacity on computed tomography (CT) imaging (12). CT abnormalities were observed in both asymptomatic or symptomatic patients with SARS-CoV-2 infection, making it a useful diagnostic tool. Asymptomatic individuals with CT abnormalities rarely developed severe pneumonia (13). Initial symptoms were fever, cough, dyspnea, myalgia or fatigue, sputum production, headache, hemoptysis, and diarrhea. In most severe cases, there was a progression to ARDS, to acute cardiac injury, to acute kidney injury (AKI), or to shock. Other symptoms that were identified pertained to the gastrointestinal system (nausea and diarrhea) (12). However, other studies showed a lower development of gastrointestinal symptoms $(14,15)$. Moreover, an increase in serum lactate dehydrogenase as marker of lung tissue damage was observed in COVID-19 patients (13), and it was associated with higher odds of severe disease (14). Additionally, older age and lymphopenia were identified as potential risk factors for severe COVID-19 (13).

\section{CLASSIC AND NON-CLASSIC RAS}

The classic RAS involves as main effector peptide the angiotensin II (AII), whose synthesis starts with the cleavage of angiotensinogen into angiotensin I (AI) by the renin and then its conversion into AII by the ACE (16) (Figure 1). Despite this represent the main pathway for the AII production, also other enzymes can be involved (5). The main effects of AII are explained by its interaction with three receptors (AT1, AT2, and nonAT1nonAT2). AT1 and AT2 are classified as G protein-coupled receptors (16), while nonAT1nonAT2 seems more prone to be an angiotensin clearance receptor or an angiotensinase (17). The stimulation of the AT1 receptor can induce vasoconstriction, increase the release of catecholamines and the synthesis of aldosterone (16). Moreover, AT1 receptors can stimulate fibrosis, inflammatory processes, reduction of collagenase activity, and expression of mitogen-activated protein kinase (MAPK) $(2,5)$. As pro-inflammatory action, these receptors seem to be involved in several pathways: down-regulation of the NADPH oxidase expression in smooth muscle cells; enhancement of the production of reactive oxygen species (ROS) and the activity of pro-inflammatory transcription nuclear factors like nuclear factor-kappaB (NF-kB) and E26 transformation-specific sequence (Ets) (18); release of different types of cytokines such as TNF- $\alpha$, IL-6, and MCP-1 (19); shifting of the macrophage phenotype toward the proinflammatory M1 polarization state (20). The stimulation of AT2 receptors, instead, has a protective role in the RAS activation inducing anti-inflammatory, anti-oxidative, and anti-fibrotic effects (16).

The non-classic RAS involves, instead, other peptide mediators and enzymes. Specifically, the main mediator is the angiotensin 1-7 (A1-7), whose synthesis can involve two different pathways. One starts with the cleavage of AII into A1-7 by the carboxypeptidase ACE2, while another through the cleavage of AI into angiotensin 1-9 (A1-9) by ACE2 and its subsequent conversion into A1-7 by ACE (5) (Figure 1). Today, two forms of ACE2 are recognized, one soluble and another transmembrane, both contributing to the generation of A1-7. The A1-7 stimulates the G protein-coupled receptor MAS1, promoting the nitric oxide release (21), Akt phosphorylation (22), and anti-inflammatory effects (23). Moreover, the activation of MAS1 receptors, expressed on the macrophage surface, inhibits the inflammatory macrophage phenotype and the release of pro-inflammatory cytokines (5). Therefore, A1-7 is a component of a beneficial axis of the RAS that exerts opposite cardiovascular and renal effects compared to the ACE/AII/AT1 axis (24).

Interestingly, it has been found that human monocytes can express ACE and ACE2 and metabolize AI to multiple angiotensin peptides. In particular, classical monocytes $\left(\mathrm{CD} 14^{++} \mathrm{CD} 16^{-}\right)$produce both AII and A1-9/A1-7, whereas the non-classical subtype $\left(\mathrm{CD} 14^{+} \mathrm{CD} 16^{++}\right)$produces mainly A1-7 (25). This indicates that ACE and ACE2 participate to the inflammation also as components of a local RAS at sites infiltrated by monocytes/macrophages. 


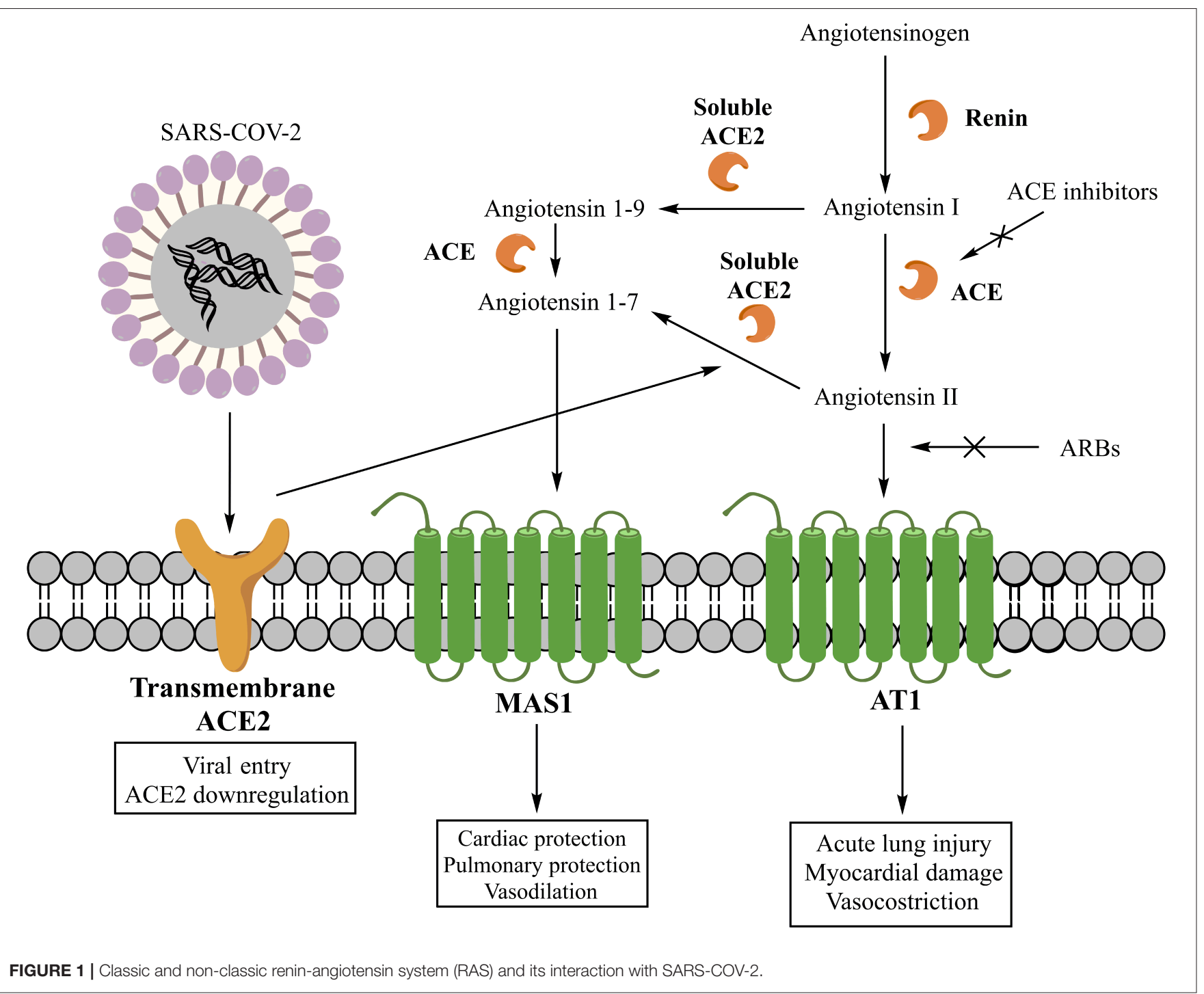

\section{SARS-COV-2 AND ACE2 IN THE LUNG}

SARS-COV-2 is a betacoronavirus with a single-stranded positive-sense RNA genome encapsulated within a membrane envelope (26). The genome encodes for several structural proteins, including the glycosylated spike (S) protein that is a major inducer of host immune response. The $S$ protein is also important because mediates host cell invasion by SARS-COV-2 via binding to the receptor protein ACE2 present on the surface of lung alveolar epithelial cells (host cells) $(6,27)$. The affinity of $S$ protein binding region to the extracellular domain of ACE2 has been estimated of $15 \mathrm{nM}(27,28)$. The invasion process requires the activation of the $\mathrm{S}$ protein, which is facilitated by the human androgen-sensitive transmembrane serine protease type 2 (TMPRSS211) $(6,26)$. Specifically, TMPRSS211 cleaves the S protein and generates the S1 and S2 subunits. This is a critical step as both subunits are essential for viral entry in the host cells (28). $\mathrm{S} 1$ is the subunit recognized by ACE2 and the one that facilitates viral attachment, whereas S2 is the subunit that drives membrane fusion and viral internalization in the pulmonary epithelium (6). The greater virulence of SARS-COV-2 compared to SARS-COV1 was supposed to be related to the higher affinity of S1 subunit for ACE2 $(26,28)$. In fact, a Cryo-EM structure analysis revealed that the affinity of the S protein of SARS-COV-2 to ACE2 is about 10-20 times greater than that observed with the $S$ protein of SARS-COV-1 (27).

Another important consideration is that the ACE2 internalization mediated by SARS-COV-2 could potentially result in a reduced presence of ACE2 on cell surface, leading to the absence of a key factor for AII degradation and A1-7 synthesis. An imbalance between AII and A1-7 levels may further exacerbate the damage of lung provoked by SARSCOV-2. Therefore, a decrease in ACE2 may contribute to the reduction of pulmonary function and the increase of tissue fibrosis and inflammation due to COVID-19 (28). This hypothesis was already investigated with SARS-COV-1 infection, 
which was associated with a reduced presence of ACE2 on cell membranes and an increased severity of lung injury (29). Because SARS-COV-1 and SARS-COV-2 share the same cellular invasion process, they may also share similar pathogenesis and pathological manifestations of lung injury (29).

\section{SARS-COV-2 AND ACE2 IN THE HEART}

Potentially, once the SARS-COV-2 enters the circulation, it can infect any tissue expressing the ACE2, including the heart or other cardiovascular tissues (28). Evidence showed that patients with COVID-19 had a high occurrence of cardiovascular symptoms, in addition to respiratory ones, and that these symptoms were also reported in patients without underlying cardiovascular diseases (30). The National Health Commission of China (NHC) reported that cardiovascular symptoms (such as heart palpitations and chest tightness) occurred at the beginning of the SARS-COV-2 infection in some of confirmed cases. Moreover, the $11.8 \%$ of patients who died for COVID-19 but without underlying cardiovascular diseases had substantial heart damage (30). These data suggest the necessity of involving cardiologists in the management of patients with COVID19 (31). However, the real contribute of SARS-COV-2 in the development of myocardial injury is not clear (32). It is known that the infection itself may directly impact cardiovascular diseases and the development of cardiovascular complications $(30,33)$. Another factor that should be considered is also the expression in the tissue of TMPRSS211 or other proteases able to trigger the viral entry (6). Another hypothesis for the induction of heart damage considers the reduction of ACE2 caused by SARS-COV-2, which might exacerbate symptoms in patients with underlying cardiovascular diseases $(28,34)$. This could be due to the imbalance between the classic and non-classic RAS in favor of AII that may further compromise cardiac function apart from the viral infection (28). In fact, a preclinical study shows that ACE2 knockout animal models had a worse left ventricular remodeling in response to the AII-induced acute injury, suggesting a protective role of nonclassic RAS in myocardial recovery (35). This finding may also explain the heart damage found in patients with COVID-19 but without cardiovascular diseases (30). To corroborate this hypothesis, a study demonstrated that the AII level in the plasma sample of SARS-COV-2 infected patients was markedly high and linearly associated with the viral load and lung injury (32). Moreover, another study found in the 35\% of heart samples from patients with SARS the presence of viral RNA associated with a reduced ACE2 protein expression (36). Another proposed mechanism of myocardial injury includes the cytokine storm (32) as the systemic inflammatory response and immune system disorders during disease progression may be responsible for the myocardial damage (30). Also, in this case, other than the viral infection itself, a minor role in potentiating the inflammation might be played by the classic RAS cascade. Moreover, needs to be considered that also some drugs that are being investigated for COVID-19 are potential risk factors for the cardiovascular toxicity (31).
Finally, evidence showed that COVID-19 may produce a form of disseminated intravascular coagulation (DIC) as the presence of microthrombi have been reported from the autopsy of patients with COVID-19 (37). To date, the exact causes of DIC are many and unclear. Potential suggested mechanisms are as follows: inflammation (e.g., IL-6) stimulates the synthesis of fibrinogen (38); or the virus may directly bind to endothelial cells; or a mutual relationship between DIC and cytokine storm (wherein each exacerbates the other) exists.

\section{CONCERNS, EVIDENCE AND RECOMMENDATION ON THE USE OF RAS INHIBITORS IN PATIENTS WITH COVID-19}

Concerns were raised on the use of RAS inhibitors in patients with COVID-19 as the use of these drugs may determine an increase of ACE2 and then of SARS-COV-2 virulence $(11,30)$. Among drugs able to inhibit the RAS, there are renin inhibitors, ACE inhibitors, and the Angiotensin Receptor Blockers (ARBs). ACE inhibitors and ARBs are among drugs most commonly used worldwide for the treatment of cardiovascular diseases. Therefore, concerns on their use in patients with COVID-19 are even more important. Initial evidence showed that patients with COVID-19 and coexisting cardiovascular conditions had a more severe illness, a more frequent admission to the intensive care unit, were more prone to receive mechanical ventilation, or to die (11). The first hypothesis was that the medical management of these conditions, including the use of RAS inhibitors, may have contributed to the adverse health outcomes. So far, there is no rigorous report accounting for key factors as potential confounders in risk prediction; moreover, available evidence on the effect of RAS inhibitors on ACE2 mRNA expression and levels are conflicting and scarce, highlighting also the absence of data on lung-specific mRNA expression of ACE2 (11). Researches have also suggested that this effect of RAS inhibitors may not be uniform among molecules $(11,39)$. Moreover, even if there was a relationship between the RAS inhibition and the upregulation of ACE2, there is no evidence demonstrating a causal relationship between the ACE2 activity and the SARS-COV-2 associated mortality (40). Furthermore, the presence of ACE2 on cell surface may not be the only factor participating in the infection process. In fact, additional co-factors might participate in the cell invasion process as SARS-COV-1 infection was not observed in some cells expressing ACE2 on the surface, whereas it was found in cells apparently without ACE2 (41). Moreover, the lethal outcome observed in patients with COVID-19 may also be driven by the severity of the lung damage. In this regard, a preclinical study suggested a beneficial role of RAS blockers in limiting the SARS-COV-1-induced lung injury (42), so that, a protective role is played by RAS inhibitors. This finding could rise a new hypothesis in which the activation of the classic RAS, rather than its inhibition, may predispose patients toward a more deleterious outcome.

Finally, another aspect that should be considered is the potential harm associated with the withdrawal of a RAS inhibitor in a patient with a stable cardiovascular condition. In fact, 
RAS inhibitors are known to determine clinical benefits and to protect both myocardium and kidney. Therefore, their sudden withdrawal may expose patients to an unjustified risk related to decompensation and symptoms exacerbation, especially in high cardiovascular risk patients. In this regard, clinical trials have demonstrated a rapid relapse of the dilated cardiomyopathy or a decline of the clinical condition after the discontinuation of the pharmacological treatment with a RAS inhibitor (43).

Moreover, there are solid evidence on the effect of RAS inhibitors in reducing mortality in patients with cardiovascular diseases. These drugs are indeed the cornerstone therapy for a favorable prognosis in patients with heart failure, with the highest level of evidence in reducing mortality (44). Finally, Scientific Societies have expressed their opinion on the use of RAS inhibitors, highlighting the absence of evidence suggesting an eventual discontinuation of ACE-inhibitors, or ARBs in patients with COVID-19. Therefore, they recommend to continue the treatment with the usual anti-hypertensive agent in patients with COVID-19 (45-49). This recommendation has been supported by different observational studies published in the last few months. In this regards, a population-based case-control study carried out in the Lombardy region of Italy did not show any association between the use of ARBs or ACE-inhibitors with COVID-19 among all patients (adjusted odds ratio, 0.95 [95\% confidence interval (CI), 0.86 to 1.05] for ARBs and 0.96 [95\% CI, 0.87 to 1.07] for ACE inhibitors) or among patients with a severe or fatal course of the disease (adjusted odds ratio, 0.83 [95\% CI, 0.63 to 1.10 ] for $\mathrm{ARBs}$ and 0.91 [95\% CI, 0.69 to 1.21] for ACE inhibitors) (50).

Accordingly, another Italian nested case-control study showed no increased risk of being infected by SARS-COV-2 in patients treated with RAS inhibitors (51). Moreover, a case-population study showed that RAS inhibitors had an adjusted odds ratio for COVID-19 requiring admission to hospital of 0.94 (95\% CI, 0.77 to 1.15 ) compared with users of other antihypertensive drugs (52). In relation to the mortality outcome, instead, a retrospective observational study showed similar mortality rates between the RAS inhibitor and non-RAS inhibitor cohorts $(2.2$ vs. $3.6 \%$, adjusted hazard ratio [HR] $0.85 ; 95 \% \mathrm{CI}, 0.28$ to 2.58) (53). Similarly, a Korean nationwide population-based cohort study showed no difference for mortality between RAS inhibitors users and non-users (adjusted odds ratio, 0.88; 95\% CI, 0.53 to 1.44 ) (54). Finally, a retrospective, multi-center study demonstrated a lower risk of COVID-19 mortality in inhospital patients with hypertension and hospitalized due to COVID-19 who received $\mathrm{ACE}$ inhibitor/ARB compared to those who did not receive an ACE inhibitor/ARB (adjusted HR, 0.37; 95\% CI, 0.15 to 0.89 ) (55). Different other published studies supported the aforementioned findings (56-58). Moreover, it is ongoing an observational study that will enroll about 2,000 participants to assess if the chronic intake of RAS inhibitors modifies the prevalence and severity of clinical manifestations of COVID-19 (ClinicalTrials.gov identifier, NCT04331574).

Clinical trials are also ongoing to assess instead clinical benefits of continuing or not the treatment with ARBs or ACE inhibitors in patients with COVID-19 (NCT04330300, NCT04351581, NCT04353596, and NCT04329195). In particular, the NCT04330300 is a randomized, open label, parallel assignment clinical trial that will randomize patients with primary essential hypertension who are already taking ACE inhibitor/ARB to either switch to an alternative antihypertensive agent or continue with the ACE inhibitor/ARB treatment. The NCT04351581 is a randomized, single mask (outcome assessor), parallel assignment clinical trial that will randomize hospitalized patients with COVID-19 to continue or discontinue their treatment with the ACE inhibitor or ARB. The NCT04353596 is also a randomized, single mask (outcome assessor), parallel assignment clinical trial that will randomize symptomatic SARS-CoV2-infected patients to stop/replace the chronic treatment with the ACE inhibitor/ARB or to continue this chronic treatment. The NCT04329195 is instead a randomized, open label, parallel assignment clinical trial that will randomize patients with a history of cardiovascular disease treated with RAS blockers, and infected by SARS-CoV-2 to stop or continue the treatment with the RAS blocker. Moreover, the substudy of the Austrian Coronavirus Adaptive Clinical Trial (ACOVACT), which is a randomized, controlled, multicenter, open-label basket trial that aims to compare various antiviral treatments for COVID-19, will also compare the sub-arm with RAS blockade vs. no RAS blockade for patients with blood pressure $>120 / 80$ $\mathrm{mmHg}$ (NCT04351724). Characteristics of the ongoing clinical trials are showed in Table 1.

\section{NEW PHARMACOLOGICAL APPROACHES FOR PREVENTING VIRAL ENTRY OF SARS-COV-2 WITH A FOCUS ON THE DISRUPTION OF S PROTEIN/ACE2 INTERACTION}

To prevent viral infection, molecules like camostat mesylate, nafamostat mesylate, gabexate, umifenovir, and hydroxychloroquine/chloroquine are being considered (26). Nafamostat and camostat are inhibitors of the protease TMPRSS211 (26). Gabexate has instead multiple mechanisms of action. It has anticoagulant and anti-platelet activities on one hand, and it is a serine protease inhibitor with antiviral and anti-inflammatory properties on the other $(59,60)$.

While these drugs act on the protease inhibition, umifenovir and hydroxychloroquine/chloroquine directly influence the $\mathrm{S}$ protein/ACE2 interaction (Table 2) (26). Hydroxychloroquine and chloroquine, in addition to their use for malaria and autoimmune diseases, may be effective also for the treatment of COVID-19. These drugs are able to elevate endosomal $\mathrm{pH}$ and interfere with ACE2 glycosylation $(26,70)$. The efficacy of chloroquine was already demonstrated with SARS-COV1 infection, in which the treatment was effective either if administrated prior or after the infection, suggesting that chloroquine may have both a prophylactic and therapeutic use (70). Moreover, preliminary in vitro results demonstrated that remdesivir and chloroquine are highly effective in the inhibition of SARS-COV-2 infection (71). Clinical findings also confirmed the efficacy of chloroquine in terms of reduction of exacerbation of pneumonia and duration of symptoms in a cohort of 100 
TABLE 1 | Characteristics of ongoing clinical trials on drugs acting either by influencing the RAS or disrupting the viral attachment to ACE2 in patients with COVID-19.

\begin{tabular}{|c|c|c|c|c|c|}
\hline $\begin{array}{l}\text { Clinical trial } \\
\text { number }\end{array}$ & $\begin{array}{l}\text { Clinical } \\
\text { phase; } \\
\text { multicenter }\end{array}$ & Arms & $\begin{array}{l}\text { Estimated } \\
\text { enrollment }\end{array}$ & Primary outcome & $\begin{array}{l}\text { Estimated study } \\
\text { completion date }\end{array}$ \\
\hline NCT04351581 & $\begin{array}{l}\text { Not reported; } \\
\text { No }\end{array}$ & $\begin{array}{l}\text { - Experimental arm: continuing the } \\
\text { treatment with ACE inhibitor/ARB. The } \\
\text { clinicians will be encouraged to continue } \\
\text { the medication throughout the hospital } \\
\text { admission but it will be permissible for } \\
\text { the clinician to stop treatment if } \\
\text { necessary (e.g., due to hypotension). } \\
\text { - Experimental arm: discontinuing the } \\
\text { treatment with ACE inhibitor/ARB. If } \\
\text { hypertensive treatment is necessary } \\
\text { during hospital admission, the clinicians } \\
\text { will first be encouraged to start } \\
\text { non-ACE inhibitor/non-ARB treatment. }\end{array}$ & 215 & $\begin{array}{l}\text { 1. Days alive and out of hospital } \\
\text { within } 14 \text { days after recruitment }\end{array}$ & December 2020 \\
\hline NCT04353596 & 4; Yes & $\begin{array}{l}\text { - Experimental arm: chronic treatment } \\
\text { with ACE inhibitor or ARB will be } \\
\text { stopped or replaced. } \\
\text { - Comparator arm: no intervention, which } \\
\text { means to continue the treatment with } \\
\text { ACE inhibitor or ARB. }\end{array}$ & 208 & $\begin{array}{l}\text { 1. Combination of maximum } \\
\text { Sequential Organ Failure } \\
\text { Assessment (SOFA) Score and } \\
\text { death at } 30 \text { days. } \\
\text { 2. Composite of admission to an } \\
\text { intensive care unit, the use of } \\
\text { mechanical ventilation, or all-cause } \\
\text { death at } 30 \text { days. }\end{array}$ & May 15, 2022 \\
\hline $\begin{array}{l}\text { NCT0 } 4351724 \\
\text { substudy }\end{array}$ & 2/3; Yes & $\begin{array}{l}\text { - Experimental arm: candesartan at } 4 \mathrm{mg} \\
\text { once daily and titrated to normotension } \\
\text { - Comparator arm: non-RAS } \\
\text { antihypertensive agents titrated to } \\
\text { normotension. Those with normal blood } \\
\text { pressure may be controlled without } \\
\text { further treatment. }\end{array}$ & 500 & $\begin{array}{l}\text { 1. Sustained improvement (>48 h) of } \\
\text { one point on the WHO Scale } \\
\text { within } 29 \text { days (daily evaluation). }\end{array}$ & $\begin{array}{l}\text { December 31, } \\
2020\end{array}$ \\
\hline NCT04260594 & $\begin{array}{l}\text { 4; Not } \\
\text { reported }\end{array}$ & $\begin{array}{l}\text { - Experimental arm: umifenovir tablets (2 } \\
\text { tablets/time, } 3 \text { times/day for } 14-20 \\
\text { days) + basic treatment } \\
\text { - Comparator arm: basic treatment } \\
\text { - The basic treatment is based on the } \\
\text { condition of the patient. }\end{array}$ & 380 & $\begin{array}{l}\text { 1. Virus negative conversion rate in } \\
\text { the first week }\end{array}$ & $\begin{array}{l}\text { December 30, } \\
2020\end{array}$ \\
\hline NCT04252885 & 4; No & $\begin{array}{l}\text { - Experimental arm: standard treatment + } \\
\text { lopinavir/ritonavir. Specifically, } 50 \\
\text { participants are given ordinary treatment } \\
\text { plus a regimen of lopinavir ( } 200 \mathrm{mg} \text { ) and } \\
\text { ritonavir ( } 50 \mathrm{mg} \text { ) (oral, q12h, every time } \\
2 \text { tablets of each, taking for } 7-14 \text { days). }\end{array}$ & 125 & $\begin{array}{l}\text { 1. The rate of virus inhibition at Day } \\
0,2,4,7,10,14 \text {, and } 21 \text {. Novel } \\
\text { corona viral nucleic acid is } \\
\text { measured in nose/throat swab at } \\
\text { each time point. }\end{array}$ & July 31, 2020 \\
\hline
\end{tabular}


TABLE 1 | Continued

\begin{tabular}{lllll}
\hline $\begin{array}{l}\text { Clinical trial } \\
\text { number }\end{array}$ & $\begin{array}{l}\text { Clinical } \\
\text { phase; } \\
\text { multicenter }\end{array}$ & Arms & $\begin{array}{l}\text { Estimated } \\
\text { enrollment }\end{array}$ & Primary outcome
\end{tabular}

\begin{tabular}{|c|c|c|c|c|c|}
\hline & & $\begin{array}{l}\text { - Comparator arm: standard treatment }+ \\
\text { umifenovir. Specifically, } 50 \text { participants } \\
\text { are given ordinary treatment plus a } \\
\text { regimen of umifenovir ( } 100 \mathrm{mg} \text { ) (oral, tid, } \\
200 \mathrm{mg} \text { each time, taking for } 7-14 \\
\text { days). } \\
\text { - No intervention arm: standard } \\
\text { treatment. Specifically, } 25 \text { cases are } \\
\text { only given ordinary treatment. }\end{array}$ & & & \\
\hline NCT04255017 & 4; No & $\begin{array}{l}\text { - Experimental arm: addition of umifenovir } \\
\text { ( } 0.2 \mathrm{~g} \text { once, } 3 \text { times a day for } 2 \text { weeks) } \\
\text { - Experimental arm: addition of oseltamivir } \\
\text { ( } 75 \mathrm{mg} \text { once, twice a day for } 2 \text { weeks) } \\
\text { - Experimental arm: addition of } \\
\text { lopinavir/ritonavir ( } 500 \mathrm{mg} \text { once, twice a } \\
\text { day for } 2 \text { weeks) } \\
\text { - No intervention arm: symptomatic } \\
\text { supportive treatment }\end{array}$ & 400 & $\begin{array}{l}\text { 1. Rate of disease remission at } 2 \\
\text { weeks. Defined for mild patients } \\
\text { as fever, cough and other } \\
\text { symptoms relieved with improved } \\
\text { lung CT, and for severe patients as } \\
\text { fever, cough and other symptoms } \\
\text { relieved with improved lung CT, } \\
\mathrm{SPO} 2>93 \% \text { or PaO2/FiO2 }>300 \\
\mathrm{mmHg}(1 \mathrm{mmHg}=0.133 \mathrm{Kpa} \text { ); } \\
\text { 2. Time for lung recovery at } 2 \text { weeks. } \\
\text { Defined as the comparison of the } \\
\text { average time of lung imaging } \\
\text { recovery after } 2 \text { weeks of } \\
\text { treatment in each group. }\end{array}$ & July 1, 2020 \\
\hline NCT04350684 & 4; No & $\begin{array}{l}\text { - Experimental arm: umifenovir }+ \\
\text { interferon- } \beta \text { 1a }+ \text { lopinavir/ritonavir }+ \\
\text { single dose of hydroxychloroquine }+ \\
\text { standards of care } \\
\text { - Comparator arm: interferon- } \beta 1 \mathrm{a}+ \\
\text { lopinavir/ritonavir }+ \text { single dose of } \\
\text { hydroxychloroquine }+ \text { standards of care }\end{array}$ & 40 & $\begin{array}{l}\text { 1. Time to clinical improvement from } \\
\text { the date of randomization until } 14 \\
\text { days later. Improvement of two } \\
\text { points on a seven-category ordinal } \\
\text { scale (recommended by the World } \\
\text { Health Organization: COVID-2019) } \\
\text { R\&D. Geneva: World Health } \\
\text { Organization) or discharge from } \\
\text { the hospital, whichever came first. }\end{array}$ & April 24, 2020 \\
\hline NCT04311177 & 2; Yes & $\begin{array}{l}\text { - Experimental arm: losartan ( } 25 \text { mg daily, } \\
\text { oral) } \\
\text { - Comparator arm: placebo } \\
\text { (microcrystalline methylcellulose, gelatin } \\
\text { capsule, oral) }\end{array}$ & 580 & $\begin{array}{l}\text { 1. Hospital Admission within } 15 \text { days. } \\
\text { Outcome reported as the number } \\
\text { of participants per arm admitted to } \\
\text { inpatient hospital care due to } \\
\text { COVID-19-related disease within } \\
15 \text { days of randomization. }\end{array}$ & April 1, 2021 \\
\hline
\end{tabular}


TABLE 1 | Continued

\begin{tabular}{|c|c|c|c|c|c|}
\hline $\begin{array}{l}\text { Clinical trial } \\
\text { number }\end{array}$ & $\begin{array}{l}\text { Clinical } \\
\text { phase; } \\
\text { multicenter }\end{array}$ & Arms & $\begin{array}{l}\text { Estimated } \\
\text { enrollment }\end{array}$ & Primary outcome & $\begin{array}{l}\text { Estimated study } \\
\text { completion date }\end{array}$ \\
\hline NCT04328012 & 2/3; Yes & $\begin{array}{l}\text { - Experimental arm: lopinavir/ritonavir } \\
\text { (400 mg/200 mg, oral, BID X 5-14 days } \\
\text { depending on availability) } \\
\text { - Experimental arm: hydroxychloroquine } \\
\text { (400 mg BID on Day 0, and } 200 \text { mg BID } \\
\text { Days 1-4, days } 1-13 \text { if available) } \\
\text { - Experimental arm: losartan ( } 25 \text { mg, oral, } \\
\text { daily X 5-14 days depending on } \\
\text { availability) } \\
\text { - Comparator arm: placebo (BID X } \\
14 \text { days) }\end{array}$ & 4,000 & $\begin{array}{l}\text { 1. National Institute of Allergy and } \\
\text { Infectious Diseases COVID-19 } \\
\text { Ordinal Severity Scale (NCOSS) at } \\
60 \text { days. Difference in NCOSS } \\
\text { scores between the different } \\
\text { treatment groups }\end{array}$ & April 1, 2021 \\
\hline NCT04335786 & 4; Yes & $\begin{array}{l}\text { - Experimental arm: valsartan for } 14 \text { days } \\
\text { at a dosage and frequency titrated to } \\
\text { blood pressure with } 80 \mathrm{mg} \text { or } 160 \mathrm{mg} \\
\text { tablets up to a maximum dose of } \\
160 \mathrm{mg} \text { b.i.d. } \\
\text { - Comparator arm: placebo for } 14 \text { days } \\
\text { (matching } 80 \text { or } 160 \mathrm{mg} \text { placebo tablets } \\
\text { at a dosage and frequency titrated to } \\
\text { systolic blood pressure) }\end{array}$ & 651 & $\begin{array}{l}\text { 1. First occurrence of intensive care } \\
\text { unit admission, mechanical } \\
\text { ventilation or death within } 14 \text { days. } \\
\text { Death is defined as } \\
\text { all-cause mortality }\end{array}$ & December 2021 \\
\hline NCT04360551 & 2; No & $\begin{array}{l}\text { Experimental arm: telmisartan (40 mg, } \\
\text { oral, daily } \times 21 \text { days) } \\
\text { - Comparator arm: placebo (once daily X } \\
21 \text { days) }\end{array}$ & 40 & $\begin{array}{l}\text { 1. Maximum clinical severity of } \\
\text { disease over the } 21 \text { day period of } \\
\text { study. Based on a modified World } \\
\text { Health Organization (WHO) } \\
\text { COVID-19 7-point ordinal scale }\end{array}$ & June 30, 2021 \\
\hline
\end{tabular}

subjects $(72,73)$. This finding led the China Authority to include these medicines in the recommendations for the prevention and treatment of COVID-19 pneumonia (73). Many other clinical studies are ongoing to evaluate the efficacy and safety of hydroxychloroquine for the pre-exposure prophylaxis, post-exposure prophylaxis, and treatment of COVID-19 (www. clinicaltrials.gov) (74). However, it should be noted that current evidence on the effects of chloroquine is conflicting. Authors of a recent systematic review underlined that, even though a rationale to justify clinical research on chloroquine in patients with COVID-19 exists, high-quality clinical trials are urgently needed (75). In addition, a further literature review (76) reported that there is limited in vitro evidence on the efficacy of this drug against SARS-COV-2 and that clinical data based on studies with small sample size and affected by methodological limitations $(77,78)$. Therefore, high quality randomized clinical trials are strongly needed. Umifenovir interferes instead with the attachment of viral envelope protein to host cells (26). Umifenovir is an antiviral agent actually authorized in Russia, but not in Europe, for the treatment of Influenza A and B. This drug is considered safe and it is patented for the SARS treatment (79). The opinion of the Italian Medicine Agency on this drug is that evidence on its efficacy are not sufficient to support its use in patients with COVID-19 (80). Currently, a randomized, open label, parallel assignment clinical study is evaluating the efficacy and safety of umifenovir for the treatment of pneumonia in patients infected with SARS-COV-2 (NCT04260594). In this study, patients will be randomized to receive umifenovir plus basic treatment or just the basic treatment (Table 1). Moreover, two clinical trials are ongoing to assess the efficacy and safety of umifenovir and lopinavir/ritonavir (NCT04252885) or umifenovir, oseltamivir, and lopinavir/ritonavir (NCT04255017). Specifically, the NCT04252885 is a randomized, open label, parallel assignment clinical trial that will randomize patients with SARS-COV-2 infection in three groups (2:2:1). One group will receive the standard treatment plus lopinavir/ritonavir; the second group will receive standard treatment plus umifenovir; finally, the third group will just receive the standard treatment. The NCT04255017 is instead a randomized, single mask (participants), parallel assignment clinical trial that will randomize COVID-19 patients in four arms. One arm will receive the treatment with umifenovir; the second arm will receive the treatment with oseltamivir; the third arm will receive the treatment with lopinavir/ritonavir; the last arm will just receive the symptomatic supportive treatment (Table 1). Another small, randomized, triple mask (Participant, Care Provider, Investigator), parallel assignment clinical trial will be conducted on patients who have a positive test confirming COVID-19 to evaluate the combined treatment with umifenovir, interferon- $\beta$ 1a, lopinavir/ritonavir, single dose of hydroxychloroquine, and the standards of care compared to the same combined treatment without umifenovir (NCT04350684).

In addition, speculations were done on the possible use for COVID-19 of new compounds, never approved before, which 
TABLE 2 | Mechanism of action, main adverse events and potential drug-drug interactions of inhibitors of viral invasion interfering with the S protein/ACE2 interaction, RAS inhibitors, and analogous ACE2 and A1-7 under clinical evaluation for the treatment of COVID-19.

\begin{tabular}{|c|c|c|c|c|c|}
\hline $\begin{array}{l}\text { Therapeutic } \\
\text { class }\end{array}$ & Drugs & $\begin{array}{l}\text { Main mechanism of } \\
\text { action }\end{array}$ & Main adverse events & Drug-drug interactions & References \\
\hline \multirow[t]{2}{*}{$\begin{array}{l}\text { Inhibitors of S } \\
\text { protein/ACE2 } \\
\text { interaction }\end{array}$} & $\begin{array}{l}\text { Chloroquine/ } \\
\text { Hydroxychloroquine }\end{array}$ & $\begin{array}{l}\text { Increase of endosomal pH } \\
\text { and interference with ACE2 } \\
\text { glycosylation }\end{array}$ & $\begin{array}{l}\text { Cardiovascular disorders, } \\
\text { including prolongation of QT }\end{array}$ & $\begin{array}{l}\text { Digoxin, class IA and III } \\
\text { antiarrhythmic, tricyclic } \\
\text { antidepressants, antipsychotics }\end{array}$ & $(61,62)$ \\
\hline & Umifenovir & $\begin{array}{l}\text { Interference with the } \\
\text { attachment of the viral } \\
\text { protein to host cells }\end{array}$ & $\begin{array}{l}\text { Gastrointestinal symptoms } \\
\text { and increased transaminase }\end{array}$ & $\begin{array}{l}\text { As UDP-glucuronosyltransferase } 1 \text { A9 } \\
\text { and 2B7 inhibitor, umifenovir can } \\
\text { increase levels of its substrates } \\
\text { (paracetamol, buprenorphine, etc.) } \\
\text { Cytochrome 3A4 inducers can } \\
\text { reduce umifenovir levels }\end{array}$ & $(63,64)$ \\
\hline ARBs & Losartan & $\begin{array}{l}\text { Blocks the All-induced lung } \\
\text { injury }\end{array}$ & $\begin{array}{l}\text { Dizziness, anemia, renal } \\
\text { failure, asthenia, } \\
\text { hyperkaliemia }\end{array}$ & $\begin{array}{l}\text { Fluconazole and } \\
\text { Rifampicine can increase losartan } \\
\text { levels, } \\
\text { Potassium-sparing diuretics can } \\
\text { increase the risk of hyperkaelemia }\end{array}$ & $(65,66)$ \\
\hline \multirow[t]{2}{*}{$\begin{array}{l}\text { Analogous of } \\
\text { ACE2 and A1-7 }\end{array}$} & $A 1-7$ & $\begin{array}{l}\text { Restores the beneficial } \\
\text { effect of the non-classic } \\
\text { RAS }\end{array}$ & $\begin{array}{l}\text { Headache, fatigue, injection } \\
\text { site reaction }\end{array}$ & Not Available & $(29,67,68)$ \\
\hline & ACE2 & $\begin{array}{l}\text { Restores the beneficial } \\
\text { effect of the non-classic } \\
\text { RAS }\end{array}$ & $\begin{array}{l}\text { Hypernatremia, rash, } \\
\text { dysphagia, and pneumonia }\end{array}$ & Not Available & (69) \\
\hline
\end{tabular}

have shown the ability of interfering with $S$ protein/ACE2 interaction (74). The compound SSAA09E2 showed the ability of blocking the early interaction of SARS-S protein with ACE2 in ACE2-expressing 293T cells (81). Moreover, the agent VE607 also showed a significant inhibition of SARS-pseudovirus entry in the same cellular model (82).

\section{NEW PHARMACOLOGICAL PERSPECTIVE FOR COVID-19 ACTING ON THE RAS}

Based on the beneficial role of the non-classic RAS, which seems lacking in patients with COVID-19, hypotheses have been made on the potential therapeutic approach of restoring the ACE2/A1-7 pathway. This hypothesis is based on preclinical evidence showing an improvement of oxygenation, reduction of inflammation, and reduction of tissue fibrosis after infusion of A1-7 in two models of ARDS $(65,83)$. Evidence also showed that the administration of the soluble human recombinant ACE2 was able to reverse the lung-injury process in preclinical models of other viral infections $(84,85)$. The rationale to administer soluble ACE2 is to stimulate the RAS protective pathway without increasing the ACE2 transmembrane form that could instead potentiate the viral entry into the cells. Clinical evidence on this aspect is scarce (86). A phase 2 trial conducted in patients with ARDS showed that ACE2 infusion safely reduced the AII level, but this trial was not powered enough to show efficacy in terms of pulmonary function (69). Restoring the ACE2 activity may also be beneficial for the myocardial protection in patients with COVID-19 (87). To date, clinical researches are ongoing to assess the clinical impact of a restoration of the nonclassic RAS (ACE2 and A1-7) in patients with COVID-19. Is underway a controlled trial aimed to assess the efficacy, safety and clinical impact of A1-7 infusion in a cohort of COVID19 patients requiring mechanical ventilation (NCT04332666). It was, instead, suspended a further clinical trial that aimed to assess preliminary biologic, physiologic, and clinical data with the use of ACE2 recombinant compared to the standard care in patients with COVID-19 (NCT04287686).

In addition, based on the organ protective effects of RAS inhibitors, many studies are being conducted to investigate their efficacy in COVID-19 patients. The beneficial effects of ACE inhibitors and ARB may be related to the prevalence of ACE2/A1-7 effects as demonstrated in experimental studies $(88,89)$. Moreover, experimental evidence strongly suggests that AII could promote acute lung injury induced by different coronaviruses, including SARS-COV-1 and SARS-COV-2 $(42,65)$. Therefore, the use of RAS inhibitors may block the deleterious effect associated with AII. Two trials are ongoing to investigate the role of losartan for the treatment of COVID-19 in patients who have not previously received a RAS inhibitor and are either hospitalized (NCT04312009) or not hospitalized (NCT04311177). In particular, both trails (NCT04312009 and NCT04311177) are randomized, quadruple mask (participant, care provider, investigator, outcomes assessor), parallel assignment clinical trials that will compare the treatment with losartan vs. placebo in COVID-19 patients, including those with ARDS. Moreover, a pragmatic adaptive, randomized, quadruple mask (participant, care provider, investigator, outcomes assessor), parallel assignment trial is comparing the 
treatment with lopinavir/ritonavir, or hydroxychloroquine, or losartan vs. placebo in patients with COVID-19 (NCT04328012). Another randomized, quadruple mask (participant, care provider, investigator, outcomes assessor), parallel assignment clinical trial will evaluate the treatment with valsartan compared to placebo for the prevention of ARDS in hospitalized patients with COVID-19 (NCT04335786). Finally, a pilot, randomized, triple mask (participant, care provider, investigator), parallel assignment clinical trial is ongoing to assess the safety and efficacy of telmisartan compared to placebo for the mitigation of pulmonary and cardiac complications in COVID-19 patients (NCT04360551). Characteristics of the mentioned clinical trials are showed in Table 1. The mechanism of action, main adverse events and potential drug-drug interactions of RAS inhibitors and analogous of A1-7 and ACE2 under clinical evaluation for COVID-19 are summarized in Table $\mathbf{1}$.

Finally, other compounds that may be useful for the treatment of COVID-19, but not currently evaluated, are molecules that may adjust the imbalance between AT1 and AT2 receptors such as compound 21 (C-21), CGP-42112A, and L-163491 (26). C-21 and CGP-42112A are two agonists of AT2 receptors, whereas L163491 has a dual action as a partial agonist of AT2 receptors and a partial antagonist of AT1 receptors (26).

\section{CONCLUSION}

The RAS may play a complex role in SARS-COV-2 infection. SARS-COV-2 internalization may cause a reduction of ACE2 on cell surface. A reduction in ACE2 can further contribute to the pulmonary function deterioration and the myocardial damage. However, there is a paucity of clinical evidence on the efficacy of restoring the ACE2 functionality for the treatment of viralinduced lung injury. A clinical trial is ongoing to evaluate the

\section{REFERENCES}

1. Turner AJ, Hiscox JA, Hooper NM. ACE2: from vasopeptidase to SARS virus receptor. Trends Pharmacol Sci. (2004) 25:2914. doi: 10.1016/j.tips.2004.04.001

2. Mascolo A, Sessa M, Scavone C, De Angelis A, Vitale C, Berrino L, et al. New and old roles of the peripheral and brain renin-angiotensin-aldosterone system (RAAS): focus on cardiovascular and neurological diseases. Int $J$ Cardiol. (2017) 227:734-42. doi: 10.1016/j.ijcard.2016.10.069

3. Skov J, Persson F, Frøkiær J, Christiansen JS. Tissue renin-angiotensin systems: a unifying hypothesis of metabolic disease. Front Endocrinol. (2014) 5:23. doi: $10.3389 /$ fendo.2014.00023

4. Marshall R. The pulmonary renin-angiotensin system. Curr Pharm Des. (2005) 9:715-22. doi: 10.2174/1381612033455431

5. Mascolo A, Urbanek K, De Angelis A, Sessa M, Scavone C, Berrino L, et al. Angiotensin II and angiotensin 1-7: which is their role in atrial fibrillation? Heart Fail Rev. (2020) 25:367-80. doi: 10.1007/s10741-01909837-7

6. Hoffmann M, Kleine-Weber H, Schroeder S, Krüger N, Herrler T, Erichsen $\mathrm{S}$, et al. SARS-CoV-2 cell entry depends on ACE2 and TMPRSS2 and is blocked by a clinically proven protease inhibitor. Cell. (2020) 181:27180.e8. doi: 10.1016/j.cell.2020.02.052

7. Li W, Moore MJ, Vasllieva N, Sui J, Wong SK, Berne MA, et al. Angiotensinconverting enzyme 2 is a functional receptor for the SARS coronavirus. Nature. (2003) 426:450-4. doi: 10.1038/nature02145 effect of A1-7 in COVID-19 patients. To date, there is no effective drug for the treatment of COVID-19 and few clinical data are available. Some clinical trials are ongoing to evaluate the efficacy of drugs that could interfere with the $S$ protein/ACE2 interaction such as umifenovir and hydroxychloroquine/chloroquine.

Data instead on the increased mRNA expression and levels of ACE2 after treatment with RAS inhibitors are scarce and to date not associated with an increased mortality in patients with COVID-19. Currently, clinical trials are ongoing to investigate the use of a RAS inhibitor for the reduction of the lung damage in patients with COVID-19. Substantial evidence is needed to guide decision-making on the use of ACE inhibitors and ARBs in such patients, until then we need to base on the available data that place RAS inhibitors among the safe choices for cardiovascular diseases.

\section{AUTHOR CONTRIBUTIONS}

AM, CS, CR, CF, GR, LB, GP, FR, and AC: drafting the work, revising it for important intellectual content, final approval of the version to be published, and agreement to be accountable for all aspects of the work in ensuring that questions related to the accuracy or integrity of any part of the work are appropriately discussed. FR and AC developed the concept and designed the study. AM wrote the paper. All authors contributed to the article and approved the submitted version.

\section{ACKNOWLEDGMENTS}

We are grateful for the help and support of the Italian Society of Pharmacology (SIF) and its Section of Clinical Pharmacology Giampaolo Velo. All authors who contributed significantly to the work are listed.
8. Guo YR, Cao QD, Hong ZS, Tan YY, Chen SD, Jin HJ, et al. The origin, transmission and clinical therapies on coronavirus disease 2019 (COVID-19) outbreak - an update on the status. Mil Med Res. (2020) 7:11. doi: 10.1186/s40779-020-00240-0

9. Huang C, Wang Y, Li X, Ren L, Zhao J, Hu Y, et al. Clinical features of patients infected with 2019 novel coronavirus in Wuhan, China. Lancet. (2020) 395:497-506. doi: 10.1016/S0140-6736(20)30183-5

10. Mori J, Oudit GY, Lopaschuk GD. SARS-CoV-2 perturbs the reninangiotensin system and energy metabolism. Am J Physiol Metab. (2020) 319:E43-7. doi: 10.1152/ajpendo.00219.2020

11. Vaduganathan M, Vardeny O, Michel T, McMurray JJ V, Pfeffer MA, Solomon SD. Renin-angiotensin-aldosterone system inhibitors in patients with covid19. N Engl J Med. (2020) 382:1653-9. doi: 10.1056/NEJMsr2005760

12. Jiang F, Deng L, Zhang L, Cai Y, Cheung CW, Xia Z. Review of the clinical characteristics of coronavirus disease 2019 (COVID-19). J Gen Intern Med. (2020) 35:1545-9. doi: 10.1007/s11606-020-05762-w

13. Tabata S, Imai K, Kawano S, Ikeda M, Kodama T, Miyoshi K, et al. Clinical characteristics of COVID-19 in 104 people with SARS-CoV-2 infection on the diamond princess cruise ship: a retrospective analysis. Lancet Infect Dis. (2020). doi: 10.1016/S1473-3099(20)30482-5. [Epub ahead of print].

14. Colaneri M, Sacchi P, Zuccaro V, Biscarini S, Sachs M, Roda S, et al. Clinical characteristics of coronavirus disease (COVID-19) early findings from a teaching hospital in Pavia, North Italy, 21 to 28 February 2020. Eurosurveillance. (2020) 25:2000460. doi: 10.2807/1560-7917.ES.2020.25.16.2000460 
15. Guan WJ, Ni ZY, Hu Y, Liang WH, Ou CQ, He JX, et al. Clinical characteristics of coronavirus disease 2019 in China. N Engl J Med. (2020) 382:170820. doi: 10.1056/NEJMoa2002032

16. Unger $T$. The role of the renin-angiotensin system in the development of cardiovascular disease. Am J Cardiol. (2002) 89:3A-9. doi: 10.1016/S0002-9149(01)02321-9

17. Karamyan VT, Arsenault J, Escher E, Speth RC. Preliminary biochemical characterization of the novel, non-AT1, non-AT2 angiotensin binding site from the rat brain. Endocrine. (2010) 37:442-8. doi: 10.1007/s12020-010-9328-2

18. Marchesi C, Paradis P, Schiffrin EL. Role of the renin-angiotensin system in vascular inflammation. Trends Pharmacol Sci. (2008) 29:36774. doi: 10.1016/j.tips.2008.05.003

19. Dandona P, Dhindsa S, Ghanim H, Chaudhuri A. Angiotensin II and inflammation: the effect of angiotensin-converting enzyme inhibition and angiotensin II receptor blockade. J Hum Hypertens. (2007) 21:207. doi: 10.1038/sj.jhh.1002101

20. Yamamoto S, Yancey PG, Zuo Y, Ma LJ, Kaseda R, Fogo AB, et al. Macrophage polarization by angiotensin II-type 1 receptor aggravates renal injury-acceleration of atherosclerosis. Arterioscler Thromb Vasc Biol. (2011) 31:2856-64. doi: 10.1161/ATVBAHA.111.237198

21. Fraga-Silva RA, Pinheiro SVB, Gonçalves ACC, Alenina N, Bader M, Santos RAS, et al. The antithrombotic effect of angiotensin-(17) involves mas-mediated NO release from platelets. Mol Med. (2008) 14:28-35. doi: 10.2119/2007-00073.Fraga-Silva

22. Dias-Peixoto MF, Santos RAS, Gomes ERM, Alves MNM, Almeida PWM, Greco L, et al. Molecular mechanisms involved in the angiotensin-(17)/Mas signaling pathway in cardiomyocytes. Hypertension. (2008) 52:5428. doi: 10.1161/HYPERTENSIONAHA.108.114280

23. da Silveira KD, Coelho FM, Vieira AT, Sachs D, Barroso LC, Costa VV, et al. Anti-inflammatory effects of the activation of the angiotensin-(1-7) receptor, MAS, in experimental models of arthritis. J Immunol. (2010) 185:556976. doi: 10.4049/jimmunol.1000314

24. Santos RAS, Ferreira AJ, Verano-Braga T, Bader M. Angiotensin-converting enzyme 2, angiotensin-(1-7) and mas: new players of the renin-angiotensin system. J Endocrinol. (2013) 216:R1-17. doi: 10.1530/JOE-12-0341

25. Rutkowska-Zapała M, Suski M, Szatanek R, Lenart M, Weglarczyk $\mathrm{K}$, Olszanecki R, et al. Human monocyte subsets exhibit divergent angiotensin I-converting activity. Clin Exp Immunol. (2015) 181:12632. doi: $10.1111 /$ cei.12612

26. Liu C, Zhou Q, Li Y, Garner LV, Watkins SP, Carter LJ, et al. Research and development on therapeutic agents and vaccines for COVID19 and related human coronavirus diseases. ACS Cent Sci. (2020) 6:315. doi: $10.1021 /$ acscentsci.0c00272

27. Wrapp D, Wang N, Corbett KS, Goldsmith JA, Hsieh CL, Abiona O, et al. Cryo-EM structure of the 2019-nCoV spike in the prefusion conformation. Science. (2020) 367:1260-3. doi: 10.1126/science.abb2507

28. South AM, Diz D, Chappell MC. COVID-19, ACE2 and the cardiovascular consequences. Am J Physiol Hear Circ Physiol. (2020) 318:H108490. doi: 10.1152/ajpheart.00217.2020

29. Cheng H, Wang Y, Wang GQ. Organ-protective effect of angiotensinconverting enzyme 2 and its effect on the prognosis of COVID-19. J Med Virol. (2020) 96:726-30. doi: 10.1002/jmv.25785

30. Zheng YY, Ma YT, Zhang JY, Xie X. COVID-19 and the cardiovascular system. Nat Rev Cardiol. (2020) 17:259-60. doi: 10.1038/s41569-020-0360-5

31. Driggin E, Madhavan MV, Bikdeli B, Chuich T, Laracy J, Bondi-Zoccai G, et al. Cardiovascular considerations for patients, health care workers, and health systems during the coronavirus disease 2019. (COVID-19) Pandemic. J Am Coll Cardiol. (2020) 75:2352-71. doi: 10.1016/j.jacc.2020.03.031

32. Liu Y, Yang Y, Zhang C, Huang F, Wang F, Yuan J, et al. Clinical and biochemical indexes from 2019-nCoV infected patients linked to viral loads and lung injury. Sci China Life Sci. (2020) 63:364-74. doi: 10.1007/s11427-020-1643-8

33. Du L, He Y, Zhou Y, Liu S, Zheng BJ, Jiang S. The spike protein of SARS-CoV - a target for vaccine and therapeutic development. Nat Rev Microbiol. (2009) 7:226-36. doi: 10.1038/nrmicro2090

34. Yousif MHM, Dhaunsi GS, Makki BM, Qabazard BA, Akhtar S, Benter IF. Characterization of angiotensin-(1-7) effects on the cardiovascular system in an experimental model of type-1 diabetes. Pharmacol Res. (2012) 66:26975. doi: 10.1016/j.phrs.2012.05.001

35. Kassiri Z, Zhong J, Guo D, Basu R, Wang X, Liu PP, et al. Loss of angiotensin-converting enzyme 2 accelerates maladaptive left ventricular remodeling in response to myocardial infarction. Circ Hear Fail. (2009) 2:446-55. doi: 10.1161/CIRCHEARTFAILURE.108. 840124

36. Oudit GY, Kassiri Z, Jiang C, Liu PP, Poutanen SM, Penninger JM, et al. SARS-coronavirus modulation of myocardial ACE2 expression and inflammation in patients with SARS. Eur J Clin Invest. (2009) 39:61825. doi: 10.1111/j.1365-2362.2009.02153.x

37. Luo W, Yu H, Gou J, Li X, Sun Y, Li J, et al. Clinical pathology of critical patient with novel coronavirus pneumonia (COVID-19) List of authors. Preprints. (2020). [Epub ahead of print].

38. Carty CL, Heagerty P, Heckbert SR, Jarvik GP, Lange LA, Cushman M, et al. Interaction between fibrinogen and IL-6 genetic variants and associations with cardiovascular disease risk in the cardiovascular health study. Ann Hum Genet. (2010) 74:1-10. doi: 10.1111/j.1469-1809.2009.00551.x

39. Mourad JJ, Levy BI. Interaction between RAAS inhibitors and ACE2 in the context of COVID-19. Nat Rev Cardiol. (2020) 17:313. doi: 10.1038/s41569-020-0368-x

40. Kuster GM, Pfister O, Burkard T, Zhou Q, Twerenbold R, Haaf P, et al. SARS-CoV2: should inhibitors of the renin-angiotensin system be withdrawn in patients with COVID-19? Eur Hear J. (2020) 41:18013. doi: 10.1093/eurheartj/ehaa235

41. Gu J, Korteweg C. Pathology and pathogenesis of severe acute respiratory syndrome. Am J Pathol. (2007) 170:1136-47. doi: 10.2353/ajpath.2007.0 61088

42. Kuba K, Imai Y, Rao S, Gao H, Guo F, Guan B, et al. A crucial role of angiotensin converting enzyme 2 (ACE2) in SARS coronavirus-induced lung injury. Nat Med. (2005) 11:875-9. doi: 10.1038/nm1267

43. Halliday BP, Wassall R, Lota AS, Khalique Z, Gregson J, Newsome S, et al. Withdrawal of pharmacological treatment for heart failure in patients with recovered dilated cardiomyopathy (TRED-HF): an open-label, pilot, randomised trial. Lancet. (2019) 393:61-73. doi: 10.1016/S0140-6736(18)32484-X

44. Ponikowski P, Voors AA, Anker SD, Bueno H, Cleland JGF, Coats AJS, et al. ESC Guidelines for the diagnosis and treatment of acute and chronic heart failure: the task force for the diagnosis and treatment of acute and chronic heart failure of the European Society of Cardiology (ESC). Developed with the special contribution. Eur J Heart Fail. (2016) 37:2129200. doi: 10.1093/eurheartj/ehw128

45. Italian Society of Hypertension. Farmaci antiipertensivi e rischio di COVID19. Il comunicato della SIIA | SIIA. Available online at: https://siia.it/notiziesiia/farmaci-antiipertensivi-e-rischio-di-covid-19-il-comunicato-della-siia/ (accessed April 4, 2020).

46. Italian Society of Cardiology. GUIDA CLINICA COVID-19 PER CARDIOLOGI. (2020). Available online at: https://www.sicardiologia.it/ public/Documento-SIC-COVID-19.pdf (accessed April 20, 2020).

47. European Society of Cardiology. Position Statement of the ESC Council on Hypertension on ACE-Inhibitors and Angiotensin Receptor Blockers. (2020). Available online at: https://www.escardio.org/Councils/Councilon-Hypertension-(CHT)/News/position-statement-of-the-esc-council-onhypertension-on-ace-inhibitors-and-ang (accessed April 20,2020).

48. American Heart Association. HFSA/ACC/AHA statement addresses concerns re: using RAAS antagonists in COVID-19. (2020). Available online at: https:// www.acc.org/latest-in-cardiology/articles/2020/03/17/08/59/hfsa-acc-ahastatement-addresses-concerns-re-using-raas-antagonists-in-covid-19 (accessed April 20, 2020).

49. Italian Society of Pharmacology. SIF | Documento Informativo della Società Italiana di Farmacologia - Uso di Ace-Inibitori/Sartani ed infezione da COVID-19. (2020). Available online at: https://www.sifweb.org/documenti/ document_2020-03-13_documento-informativo-della-societa-italianadi-farmacologia-uso-di-ace-inibitori-sartani-ed-infezione-da-covid-19 (accessed April 17, 2020).

50. Mancia G, Rea F, Ludergnani M, Apolone G, Corrao G. Renin-angiotensinaldosterone system blockers and the risk of Covid-19. N Engl J Med. (2020) 382:2431-40. doi: 10.1056/NEJMoa2006923 
51. Gnavi R, Demaria M, Picariello Roberta, Dalmasso M, Ricceri F, Costa G. Therapy with agents acting on the renin-angiotensin system and risk of severe acute respiratory syndrome coronavirus 2 infection. Clin Infect Dis. (2020) 174:30-3. doi: 10.1093/cid/ciaa634

52. de Abajo FJ, Rodríguez-Martín S, Lerma V, Mejía-Abril G, Aguilar M, García-Luque A, et al. Use of renin-angiotensin-aldosterone system inhibitors and risk of COVID-19 requiring admission to hospital: a casepopulation study. Lancet. (2020) 395:1705-14. doi: 10.1016/S0140-6736(20) 31030-8

53. Gao C, Cai Y, Zhang K, Zhou L, Zhang Y, Zhang X, et al. Association of hypertension and antihypertensive treatment with COVID-19 mortality: a retrospective observational study. Eur Heart J. (2020) 41:2058-66. doi: 10.1093/eurheartj/ehaa433

54. Jung SY, Choi JC, You SH, Kim WY. Association of renin-angiotensinaldosterone system inhibitors with COVID-19-related outcomes in korea: a nationwide population-based cohort study. Clin Infect Dis. (2020) 22:ciaa624. doi: 10.1093/cid/ciaa624

55. Zhang P, Zhu L, Cai J, Lei F, Qin JJ, Xie J, et al. Association of inpatient use of angiotensin-converting enzyme inhibitors and angiotensin II receptor blockers with mortality among patients with hypertension hospitalized with COVID-19. Circ Res. (2020) 126:1671-81. doi: 10.1161/CIRCRESAHA.120.317242

56. Reynolds HR, Adhikari S, Pulgarin C, Troxel AB, Iturrate E, Johnson $\mathrm{SB}$, et al. Renin-angiotensin-aldosterone system inhibitors and risk of covid-19. N Engl J Med. (2020) 382:2441-8. doi: 10.1056/NEJMoa 2008975

57. Li J, Wang X, Chen J, Zhang H, Deng A. Association of reninangiotensin system inhibitors with severity or risk of death in patients with hypertension hospitalized for coronavirus disease 2019 (COVID-19) infection in Wuhan, China. JAMA Cardiol. (2020) 5:1-6. doi: 10.1001/jamacardio.2020. 1624

58. Meng J, Xiao G, Zhang J, He X, Ou M, Bi J, et al. Reninangiotensin system inhibitors improve the clinical outcomes of COVID-19 patients with hypertension. Emerg Microbes Infect. (2020) 9:757-60. doi: 10.1080/22221751.2020.1746200

59. Yuksel M, Okajima K, Uchiba M, Okabe H. Gabexate mesilate, a synthetic protease inhibitor, inhibits lipopolysaccharide-induced tumor necrosis factor$\alpha$ production by inhibiting activation of both nuclear factor- $\kappa \mathrm{B}$ and activator protein-1 in human monocytes. J Pharmacol Exp Ther. (2003) 305:298305. doi: 10.1124/jpet.102.041988

60. Tamura Y, Hirado M, Okamura K, Minato Y, Fujii S. Synthetic inhibitors of trypsin, plasmin, kallikrein, thrombin, C1r, and C1 esterase. Biochim Biophys Acta. (1977) 484:417-22. doi: 10.1016/0005-2744(77) 90097-3

61. Dong L, Hu S, Gao J. Discovering drugs to treat coronavirus disease 2019 (COVID-19). Drug Discov Ther. (2020) 14:5860. doi: $10.5582 / \mathrm{ddt} .2020 .01012$

62. Italian Medicine Agency. Plaquenil, Summary of Product Characteristics. Available online at: https://farmaci.agenziafarmaco.gov.it/aifa/servlet/ PdfDownloadServlet?pdfFileName=footer_008055_013967_RCP.pdf\&retry= 0\&sys $=$ m0b1l3 (accessed April 8, 2020).

63. Wang M, Cai B, Li L, Lin J, Su N, Yu H, et al. [Efficacy and safety of arbidol in treatment of naturally acquired influenza] - pubmed. Zhongguo Yi Xue Ke Xue Yuan Xue Bao. (2004) 26:289-93.

64. Liu X, Huang T, Chen JX, Zeng J, Fan XR, Xu-Zhu, et al. Arbidol exhibits strong inhibition towards UDP-glucuronosyltransferase (UGT) 1A9 and 2B7. Pharmazie. (2013) 68:945-50.

65. Wösten-Van Asperen RM, Lutter R, Specht PA, Moll GN, Van Woensel JB, Van Der Loos CM, et al. Acute respiratory distress syndrome leads to reduced ratio of ACE/ACE2 activities and is prevented by angiotensin(1-7) or an angiotensin II receptor antagonist. J Pathol. (2011) 225:61827. doi: 10.1002 /path. 2987

66. Italian Medicine Agency. Losaprex, Summary of Product Cheracteristics. Available online at: https://farmaci.agenziafarmaco.gov.it/aifa/servlet/ PdfDownloadServlet?pdfFileName=footer_004375_029393_RCP.pdf\&retry= 0\&sys $=$ m0b1l3 (accessed April 8, 2020).

67. Savage PD, Lovato J, Brosnihan KB, Miller AA, Petty WJ. Phase II trial of angiotensin-(1-7) for the treatment of patients with metastatic sarcoma. Sarcoma. (2016) 2016:1-7. doi: 10.1155/2016/ 4592768

68. Chappell MC. Emerging evidence for a functional angiotensinconverting enzyme 2-angiotensin-(1-7)-Mas receptor axis: more than regulation of blood pressure? Hypertension. (2007) 50:596-9. doi: 10.1161/HYPERTENSIONAHA.106.076216

69. Khan A, Benthin C, Zeno B, Albertson TE, Boyd J, Christie JD, et al. A pilot clinical trial of recombinant human angiotensin-converting enzyme 2 in acute respiratory distress syndrome. Crit Care. (2017) 21:234. doi: 10.1186/s13054-017-1823-x

70. Vincent MJ, Bergeron E, Benjannet S, Erickson BR, Rollin PE, Ksiazek TG, et al. Chloroquine is a potent inhibitor of SARS coronavirus infection and spread. Virol J. (2005) 2:69. doi: 10.1186/1743-422X-2-69

71. Wang $\mathrm{M}$, Cao R, Zhang L, Yang X, Liu J, Xu M, et al. Remdesivir and chloroquine effectively inhibit the recently emerged novel coronavirus (2019-nCoV) in vitro. Cell Res. (2020) 30:269-71. doi: 10.1038/s41422-0200282-0

72. Gao J, Tian Z, Yang X. Breakthrough: chloroquine phosphate has shown apparent efficacy in treatment of COVID-19 associated pneumonia in clinical studies. Biosci Trends. (2020) 14:72-3. doi: 10.5582/bst.2020. 01047

73. Colson P, Rolain JM, Lagier JC, Brouqui P, Raoult D. Chloroquine and hydroxychloroquine as available weapons to fight COVID-19. Int J Antimicrob Agents. (2020) 55:105932. doi: 10.1016/j.ijantimicag.2020.105932

74. U.S. National Library of Medicine. Search of: hydroxychloroquine | Covid19 - List Results - ClinicalTrials.gov. (2020). Available online at: https:// clinicaltrials.gov/ct2/results?cond=Covid-19\&term=hydroxychloroquine $\&$ cntry $=\&$ state $=\&$ city $=\&$ dist $=($ accessed April 6, 2020 $)$.

75. Cortegiani A, Ingoglia G, Ippolito M, Giarratano A, Einav S. A systematic review on the efficacy and safety of chloroquine for the treatment of COVID19. J Crit Care. (2020) 57:279-83. doi: 10.1016/j.jcrc.2020.03.005

76. Gbinigie K, Frie K. Should chloroquine and hydroxychloroquine be used to treat COVID-19? a rapid review. BJGP Open. (2020) 4:bjgpopen20X101069. doi: 10.3399/bjgpopen20X101069

77. Chen J, Liu D, Liu L, Liu P, Xu Q, Xia L, et al. A pilot study of hydroxychloroquine in treatment of patients with common coronavirus disease-19 (COVID-19). J Zhejiang Univ. (2020) 49:1-10.

78. Gautret P, Lagier J-C, Parola P, Hoang VT, Meddeb L, Mailhe M, et al Hydroxychloroquine and azithromycin as a treatment of COVID-19: results of an open-label non-randomized clinical trial. Int J Antimicrob Agents. (2020) 56:105949. doi: 10.1016/j.ijantimicag.2020.105949

79. Blaising J, Polyak SJ, Pécheur EI. Arbidol as a broad-spectrum antiviral: an update. Antiviral Res. (2014) 107:84-94. doi: 10.1016/j.antiviral.2014. 04.006

80. Italian Medicine Agency. AIFA precisa: uso umifenovir su COVID-19 non autorizzato in Europa e USA, scarse evidenze scientifiche sull'efficacia. (2020). Available online at: https://www.aifa.gov.it/web/guest/-/aifa-precisauso- umifenovir-su-covid-19-non-autorizzato-in-europa-e-usa-scarseevidenze-scientifiche-sull-efficacia (accessed April 5, 2020).

81. Adedeji AO, Severson W, Jonsson C, Singh K, Weiss SR, Sarafianos SG. Novel inhibitors of severe acute respiratory syndrome coronavirus entry that act by three distinct mechanisms. J Virol. (2013) 87:801728. doi: 10.1128/JVI.00998-13

82. Kao RY, Tsui WHW, Lee TSW, Tanner JA, Watt RM, Huang JD, et al Identification of novel small-molecule inhibitors of severe acute respiratory syndrome-associated coronavirus by chemical genetics. Chem Biol. (2004) 11:1293-9. doi: 10.1016/j.chembiol.2004.07.013

83. Zambelli V, Bellani G, Borsa R, Pozzi F, Grassi A, Scanziani M, et al. Angiotensin-(1-7) improves oxygenation, while reducing cellular infiltrate and fibrosis in experimental acute respiratory distress syndrome. Intensive Care Med Exp. (2015) 3:44. doi: 10.1186/s40635-0150044-3

84. Zou Z, Yan Y, Shu Y, Gao R, Sun Y, Li X, et al. Angiotensin-converting enzyme 2 protects from lethal avian influenza A H5N1 infections. Nat Commun. (2014) 5:3594. doi: 10.1038/ncomms4594

85. Gu H, Xie Z, Li T, Zhang S, Lai C, Zhu P, et al. Angiotensin-converting enzyme 2 inhibits lung injury induced by respiratory syncytial virus. Sci Rep. (2016) 6:19840. doi: 10.1038/srep19840 
86. Patel AB, Verma A. COVID-19 and angiotensin-converting enzyme inhibitors and angiotensin receptor blockers: what is the evidence? JAMA. (2020) 323:1769-70. doi: 10.1001/jama.2020. 4812

87. Basu R, Poglitsch M, Yogasundaram H, Thomas J, Rowe BH, Oudit GY. Roles of angiotensin peptides and recombinant human ACE2 in heart failure. J Am Coll Cardiol. (2017) 69:805-19. doi: 10.1016/j.jacc.2016. 11.064

88. Chappell MC. Biochemical evaluation of the renin-angiotensin system: the good, bad, and absolute? Am J Physiol - Hear Circ Physiol. (2016) 310:H137-52. doi: 10.1152/ajpheart.00618. 2015

89. Santos RAS, Oudit GY, Verano-Braga T, Canta G, Steckelings UM, Bader M. The renin-angiotensin system: going beyond the classical paradigms. Am J Physiol Hear Circ Physiol. (2019) 316:H958-70. doi: 10.1152/ajpheart.00723.2018

Conflict of Interest: The authors declare that the research was conducted in the absence of any commercial or financial relationships that could be construed as a potential conflict of interest.

Copyright (C) 2020 Mascolo, Scavone, Rafaniello, Ferrajolo, Racagni, Berrino, Paolisso, Rossi and Capuano. This is an open-access article distributed under the terms of the Creative Commons Attribution License (CC BY). The use, distribution or reproduction in other forums is permitted, provided the original author(s) and the copyright owner(s) are credited and that the original publication in this journal is cited, in accordance with accepted academic practice. No use, distribution or reproduction is permitted which does not comply with these terms. 